\title{
Teacher in the face of educational change - from service to resistance
}

A B S TRAC T: The changes in Polish education so far have focused on the following slogans: democracy, socialization, subjectivity, social change. The role and problems of teachers were pushed into the background. As a result, teachers have become one of the most financially marginalized professional groups. In the struggle for their rights, they first resorted to group dispute and then to strikes. Negotiations with the government on remunerations were not successful. After 21 days, the strike was suspended. This was the largest, the longest protest of teachers to date, the scope of which went beyond wage problems. What were the expectations of teachers with respect to educational authorities, what problems did they report, which environments supported striking teachers, what was the role of parents, what opinions did the teachers struggle with? These questions were answered by teachers in the ZNP Głos Nauczycielski magazine. They are the basis for the analysis of a new phenomenon, recognized to little extent in Polish pedagogy, related to teachers' resistance to authorities.

KEYWORDS: Socialization of the school, teacher's subjectivity, teacher's resistance, teachers' strike.

Today - almost 30 years after the partially free elections to the Polish Sejm, which initiated changes and transformations of the state and society - it seems reasonable to ask what did these changes bring to the Polish educational system, how did they change school and education in the Third Polish Republic? It is difficult to find a clear answer to this question. It is impossible to build a universal image of Polish education in new social and political conditions. This question will be answered differently by a historian, a political scientist, a lawyer, or an economist and, finally, differently by a social pedagogue participating in these transformations. In the general 
pedagogical view of the past 30 years of changes in Polish education, the following questions arise in the foreground: what type of school was being built?, whose school was it to be, whom it was to serve to in the first place, what goals were to be pursued, in which social, cultural and political contexts was it to be a part of?

\section{Mirages of educational democracy}

The educational changes after 1989 were based on the slogans of democracy, freedom, subjectivity and socialization. Without going into detailed discussions about the new democratic order, its most apparent trait became the fact that it carried the promise of freedom, the emancipation of the selfdetermination of the individual. As Paweł Śpiewak emphasizes, democracy means, and for many people it has meant, that the human being gains the right to create themselves, to build their own plan of life, to choose individual goals, to take appropriate actions and responsibilities for themselves and for others. Democracy has its roots in law, culture and custom, as well as in the human conscience. It builds a standardized social order that simultaneously respects the principle of pluralism of human choices and actions. Democracy both provokes and mitigates social conflicts. It is a goal as well as a principle of social order.

Democracy promises openness of public life, justice, transparency. It is supposed to give citizens the opportunity to participate in social life, to respect the rights of various social groups. It respects and strengthens democratic state, local and social institutions, including school and education. It respects legal obligations, traditions and experiences of different social structures and groups.

Democracy is inseparably connected with political and social citizenship. It creates an open public space both for social discourse reflecting different stances and interests, as well as for various diverse civic activities. (Śpiewak 2004, pp. 28-29).

Thirty years ago, the slogans of democracy, freedom, subjectivity and socialization were by no means new. However, they gained a different nature and inscribed themselves in the new shape of social sciences in Poland being democratized. Piotr Sztompka described them as new theoretical bases for becoming a society. What did they bring to social sciences, including pedagogy? Instead of the former social structures, centrally managed institutions and unified programs of the People's Republic of Poland, human beings, and more specifically - human individuals and their activities - appeared in 
the foreground. It was the human being who became a creator of change, a constructor of social conditions. People were moving away from a narrow, not to say crude level, determinism. In the new social theories, the subjective, creative human being was placed in a diverse open social space, interacting with other people. A human was building an individual and collective social world. This turn towards individualism, subjectivity and creativity emphasized by Sztompka and Jan Szczepański - resulted in a different image of social sciences.

The central place was taken by the human being, an individual, a person immersed in space and time. What is more, the social world has ceased to be treated as a permanent, unchanging state, but it would instead be treated as a continuous, dynamic process. "Society happens rather than exists, it consists of events rather than of objects" - argued Sztompka (Sztompka 1991, p. 29) at the same time convincing that social reality takes place on the so-called third level, in which all our humanity is inextricably - genetically and currently - intertwined with the surrounding social structures: normative, ideological systems, channels of interaction and the existing systems of life chances" (Sztompka 1991, p. 31). On this basis, the historical and subjective factors returned to social sciences, including pedagogy. Time became an immanent element of individual and social life, its important dimension. It gave meaning and consistency to the activities undertaken by subjective individuals and structures.

Subjectivity in the general sense means agency, the continuous process of becoming, self-fulfillment, self-transformation of an individual and the society. This is by no means a constant quality of human life. It reflects social praxis, is inscribed in history and culture, is a continuous process of creating and reproducing the individual and society. As Margaret Archer shows, the subjective praxis modifies, creates normative rules, structural networks in the society or in the environment, and at the same time transforms, develops human capital, knowledge, skills and social competences (Domecka 2013, p. 6). A new individual and structural field is created with a new potential for subjectivity leading to a new social praxis, which becomes again a field for individual action. In this way, in the morphogenetic cycle defined by Archer, social change is combined with the development of individuality, stimulating each other.

What does this combination of democracy, history and subjectivity mean for the pedagogical analysis of the changes that took place in the Polish education system of the Third Republic of Poland. It is the framework that determines the field for investigation, the relationships between the social and 
individual: between the changing time and the developed subjectivity; between what was and is potentially possible and what was done.

The subjectivity of a student and the socialization of the school became two main slogans of the Solidarity assemblies, which started to work on the changes in the Polish school after 1989. In practice, these two ideas complemented each other. "The socialization of a school cannot be only a goal, it must include a pedagogical justification; it is the subjectivity of a student as a participant in the socio-educational processes taking place at school" - wrote Julian Radziewicz, one of the independent educational experts. (Radziewicz, 1989 , p. 22). Socialization meant interruption of the monopoly of the state for the education of the young generation, establishing a local government school based on the principles of subsidiarity, solidarity and responsibility. In the new social and political conditions, the school was to become again an institution serving the child and the family, and at the same time it was to build and strengthen democratic institutional order. It was supposed to be democratic and teach democracy in practice.

This meant a different model of relations between the state, the society, the local community, the family and the school. According to the principle of subsidiarity, the state undertook to create appropriate conditions in which local communities, local governments and parents could implement the constitutional rights of children to education. The state was losing the power of "the big brother", a carer, a principal, a distributor of educational resources and contents. The illusion of apparent concern of the state for the education of children in which, in fact, under the slogans of care and support, the control of a child and a family as well as subordination to power were developing, was coming to an end. Jan Lutyński calls this process the creation of superreality (Lutyński, 1990, p. 206). In this world of divergences of experiences, of intrusive teaching of false content, an enslaved, a helpless, harmed, susceptible to manipulation human was shaped.

The People's Republic of Poland usurped the monopoly on "truth", knowledge and education. In the light of modern positions, the state cannot, of course, completely abandon the support of education and care for various marginalized social groups and individuals who find themselves in a difficult situation. This is its non-transferable task. However, the question concerns the scope and conditions of fulfilling these functions. This function is perceived differently by proponents of various political options. Differently by the left, and differently by the right. Conservative environments clearly refer to the social teaching of the Church. They stress the need not to reject but rather to revise the existing model of social and educational policy of the state. This 
implies the need to build a new social contract, to agree to a new version of civil rights derived from an integral concept of human (neither individualists nor collectivists), to create a new ethos of social solidarity, and finally to create a new participation in the life of community and society.

Involvement here is linked to socialization and governability. It is a "validation of the de-totalization of centralist power, as a result of which the involvement of all entities (actors) in the highest and best possible level of education and upbringing of children is a discursive practice" (Śliwerski 2015, p. 22). Socialization of schools is not only a legal provision and appropriate institutional solutions, but also a social praxis, a culture of education and civil society. It is a difficult, slow process of transformation of Polish education, its democratization, empowerment and socialization.

In the educational policy of the Third Republic of Poland, B. Sliwerski mentions three periods:

- The years 1980-1992. It was a phase of emancipatory rationality, i.e. maturing rebellion and resistance, proposals for changes made by Solidarity educational bodies, various expert statements related to the Round Table. In an atmosphere of openness, hope and even euphoria, various, sometimes naive postulates were born, independent structures were created, including the Civic Educational Association (Społeczne Towarzystwo Oświatowe) with the intention of building an alternative schooling system. The turning point for this period was the growing dissatisfaction and the first teacher's strikes at the turn of 1991/92.

- The years 1992-1997 - a phase defined as the restitution of technical rationality in educational policy consisting in delaying, limiting the self-government, decentralization while maintaining the appearance of emancipatory rationality.

- The years 1998-2015 were a phase of sham democratization, sham activities, hypocrisy of the authorities, hidden agenda of the reform of minister Handke. (Śliwerski 2015, p. 40).

- The next stage, after 2016, is difficult to connect with any rationality. It is rather a manipulation, it contradicts reason, it is a devastation of the educational system. Marcin Król describes this type of activity in a journalistic manner as neo-barbarity.

It should not be overlooked, however, that this slow destruction of the system was accompanied by rapid educational advancement. There has been an unprecedented increase in the number of private schools, particularly at higher level. The number of students has more than quadrupled. Some associated this phenomenon with an increase in the value of education, while 
for others it was a temporary postponement of problems with the labor market for young people in Poland.

An open question remains, what did this educational boom mean for the Polish economy for the young generation, what changes in education and higher education did it cause? To what extent were these changes connected with the socialization of schools and education in the People's Republic of Poland, to what extent did they build the subjectivity and perpetration of a teacher, student and parent?

An unambiguous answer to the first question is provided by the most recent interpretations of Maria Mendel's socialization issues (Mendel 2017; 2019), empirical diagnoses by Elżbieta Gozdawska and Danuta Uryga (Gozdawska, Uryga 2014), and extensive research by B. Śliwierski concerning the socio-political context of democratization of education in Poland and various school organs, which are to fulfill statutory tasks connected with socialization of school (Śliwerski, 2013). The conclusion of this research is a statement that in Poland there was "a specific cementation and blocking of self-government and socialization processes. The school in the Third Republic of Poland is therefore only partially public. [...] The school of the years of transformation evolved from a school as an agenda of an undemocratic state into a school helplessly and ineffectually trying to free itself from new forms of political and ideological domination" (Śliwerski 2013, p. 309). Even less can be said about the subjectivity granted to teachers, children as well as parents in the school of the Third Republic of Poland.

\section{Teacher - a member of intelligentsia - the social matrix of conformism}

It is generally accepted that teachers are the most important force of change in Polish education. But what does this power mean, to what extent is it linked to the intellectual condition of teachers and their preparation for work, to what extent can it be linked to a sense of perpetration and real change, and to what extent does it relate to the social status of the teaching profession, teaching resources, teaching citizenship and participation? These are various questions belonging to the basics of pedagogy, the sociology of the profession, as well as social and educational policy.

What is the educational awareness of teachers, to what extent can we talk about the intellectualization of teaching as a challenge of the times of transformation? - such a question was posed by Joanna Rutkowiak in the face of coming social and political change. The author accepted also "that the 
intellectual dimension of teacher's work is important for the successful course of democratic changes" (Rutkowiak 1995, p. 285). Are the teachers ready for such changes - Rutkowiak asked 20 years ago. She placed teachers among the intelligentsia which, on the one hand, inherit the former intelligent or noble ethos of social engagement and service. They are capable of fighting in the name of socially shared values. They are ready to make sacrifices in the name of defending freedom, dignity and social justice. The opposite of such ethic, not to say romantic intelligentsia, is professional intelligentsia focused on practical rationality. These are people who focus their activities on a chosen professional field, often achieving success in various areas. They combine professional mastery with individual activities. They focus on the work with a student and the so-called learning outcomes. They distance themselves from issues that go beyond the everyday life of school, avoid conflicts, try not to notice, omit the conflict-generating social, political, cultural, religious and economic contexts that determine the work of the school and the teacher.

This was the role attributed by the system of the Polish People's Republic to teachers, giving them an illusory sense of security, stability and professionalism. In these conditions, as shown by earlier research by Mikołaj Kozakiewicz (Kozakiewicz 1961) and Tadeusz Malinowski (Malinowski 1968), some teachers subordinated themselves to the model of pedagogy which was supposed to serve the achievement of goals set from the top. They reduced their role to implementing recommendations, instructions from the authorities, which effectively surrounded teachers and built up beliefs that education is inseparable from ideology. Party affiliation and political commitment were not only a criterion for teacher assessment, but also brought privileges related to professional and financial promotions.

The low economic status of Polish teachers in the period of the Polish People's Republic was not incidental. It allowed the authorities to manipulate the teaching profession, divide and conflict different groups, introduce open and hidden mechanisms of internal control, as well as recruit teachers to special services and tasks. The authorities used to mislead, buy teachers, give vouchers to the meritorious ones, and create the appearance of hope for future prosperity (Śliwerski 2013).

At the same time, however, a large part of the teaching staff did not give in to these pressures or temptations. At the cost of great efforts, many sacrifices, including financial ones, they confirmed the traditional ethos of the teaching profession and manifested its attachment to cultural and religious values. In difficult social and political conditions, they sometimes secretly smuggled the ideas of a democratic society. They created islands of resistance in 
which the intellectual ethos of a teacher in the service of public enlightenment and friendly help for a child, family or local community was maintained and reproduced to some extent. The teacher, a member of intelligentsia, did not distance themselves from reality.

Social involvement, social service - as Helena Radlińska described it - was a part of the intelligentsia ethos. The version of the People's Republic of Poland had a specific character. The teachers were by no means a group of social revolutionists (Gulczyńska, Jamrożek 2013). They rather adopted a romantic model of the intelligentsia suspended in two opposing spaces and time vectors. On a daily basis, teachers in the People's Republic of Poland struggled with a false ideology and often hostile school environment, with inadequate education, their domestic poverty, lack of access to goods and services, which they considered necessary attributes of intelligentsia (books, theater, cinema, etc.). According to the professional ethos, "they built the future, served the unknown". They compensated for their poverty and enslavement with high social status, vision of change, hope for a better future for the young generation, society and the state. One can see in it the intelligent, romantic strategy of shifting the significance of material goods in the name of higher values, postponed recognition of current work, search for professional satisfaction in the name of universal meanings and senses.

The characteristic thing is that after the 1989 coup not only new political forces, but also social activists and academic community turned to this ethic role of a teacher as a member of intelligentsia. It was hoped that the new situation would bring the possibility of de-ideologization, de-monopolization and socialization of the education system. It also creates opportunities for new alternative curricula. (Nowosad 2001, p. 255). In the new social and political situation, teachers were given tasks that did not fit well with the experience and professional attitudes shaped in the Polish People's Republic. They were combined with the rights of students and parents into the general principle of tri-subjectivity. It obligated teachers, children and parents to cooperation and self-fulfillment, to have a genuine dialog, to negotiate, to make decisions together, to build trust between these entities and to search for common values.

Various research on teachers has brought many interesting but partial answers to the question on how and to what extent teachers have joined the change. What path did they choose between normative socialization patterns and new market-oriented strategies, what career paths opened up for them and what paths did they create themselves. At the same time, these studies showed a growing dissonance between different matrices for defining and analyzing 
the teaching profession (Kędzierska 2012). On the one hand, people talked about dominance of the meritocratic perspective (Dolata 2005, p. 5), while at the same time the research indicated growing financial problems of teachers, fears related to employment, taking up additional paid classes.

The analysis of the press discourse showed that in the public space a new image of a teacher is slowly being created, built by centers of power and knowledge (Dobrołowicz 2013). A lot of attention is paid to new opportunities for promotion of teachers, financial perspectives of this profession, which do not correspond to real professional efforts of teachers. Moreover, teachers are increasingly blamed for poor educational outcomes at primary, secondary and higher levels of education. They are accused of mediocrity, of unjustified financial claims. The teaching profession is becoming less socially prestigious, romantic myths about the intellectual ethos of teachers, their service to children, family and society in the name of higher social and cultural values are becoming a thing of the past.

A professional teacher, guided by pragmatic reasons, comes to the fore. The meritocratic perspective on the analysis of the teaching profession is becoming less and less relevant. Socio-economic and social conditions of teaching work are becoming increasingly clear. Resistance among teachers occurs.

Pedagogues are not willing to deal with the economic distribution of financial resources, to look at reality from the point of view of social problems, to see social inequalities, to struggle with more or less legitimate social injustices related to wages, financial incomes and the purchasing power of teachers' salary. The data on this subject vary. According to the Central Statistical Office (GUS), the average gross salary (without annual bonuses) in the sector of education in the first quarter of 2019 amounted to PLN 4202.50 and was equal to $109.7 \%$ of the average salary. (GUS 2019, p. 29). Politicians of the current government point out that teachers' salary depends on the length of service, degree or institution in which they teach. They include variety of possible municipality-funded allowances granted by the school headmasters. On the other hand, teachers, especially teacher trade unions, use the minimum wage indicators, which since April 2018 has amounted to PLN 2417 for a trainee teacher, PLN 2487 for a contract teacher, and PLN 3318 for a nominated teacher. The highest minimum salary is paid to a certified teacher and amounts to PLN 3317.

The use of average wages is not the best measure. Much better indicator is the median salary. In 2017, it amounted to PLN 3205 for teachers with the national average at the level of PLN 4157. The social problem seems to 
be not so much the earnings of teachers themselves, but the economic status of this profession, the comparison of teachers' salaries with those of people with higher education. As the OECD Education at a Glance report shows, in 2017 the average salary of teachers in kindergartens amounted to $72 \%$ of the average salary of other people with higher education. In primary schools and high schools this ratio was $84 \%$. In 2018, this situation, in comparison with other professional groups, worsened even more, on average for all teaching groups it amounted to $0.72 \%$ of earnings in the national economy. Such relations are characteristic of most countries, not only European ones. The point is that in Poland they mean low purchasing power condemning teachers to marginalization. Perhaps it is no coincidence that in the countries such as: the Czech Republic, Turkey, Slovakia, Lithuania, Hungary, Poland, teachers are so strongly economically depraved. The poverty of teachers, on the one hand, confirms the ethos-related conformism of this group and sometimes forces some people to be ready for special political and party tasks. On the other hand, it is increasingly giving rise to dissatisfaction and resistance to power, professional disputes and strikes (Education at a Glance 2018).

\section{The teachers' strike}

Strikes are a form of trade union protest, they concern working conditions and wages to a large extent, are regulated by law and are subject to established procedures. Teachers' strikes are a phenomenon that is permanently inscribed in the 100-year history of teacher's trade unions. One-day teacher's protests took place previously in the years: 1992, 1993, 1999, 2007, 2008, 2017. A collective dispute with the Ministry of National Education and the Polish government, followed by a strike in 2019, turned out to be a unique and special event in the history of Polish teaching.

In accordance with the Constitution of the Republic of Poland, the Charter of Fundamental Rights of the European Union, the International Covenant on Economic, Social and Cultural Rights, the Convention for the Protection of Human Rights and Fundamental Freedoms (ratified by Poland in 1993) - the Main Board of the Association of Polish Teachers (ZNP) in response to earlier, ineffective discussions with the Ministry of National Education, adopted a resolution on entering into collective dispute ${ }^{1}$. They

\footnotetext{
The analysis of the teachers' strike was based on materials published in the „Głos Nauczycielski” magazine 2019, no. 1-21.
} 
obligated the local branches to present pay demands in the amount of one thousand zlotys to employers by 8 February. These protests were also joined by the teacher's "Solidarity" and the teacher's department of the Trade Unions Forum. Negotiations with the educational authorities did not bring any results and the preparation for the strike, preceded by a teacher's referendum, began. According to the information of ZNP of March 3,79.5\% of educational institutions in Poland, namely 15,549 schools and kindergartens, declared their participation in the strike (Głos Nauczycielski magazine, hereinafter GN] 2019 no. 14). The Ministry of National Education used different calculations.

On April 27, 2019, the strike was suspended. It formally lasted 21 days, while in reality the tension was building up much longer. According to ZNP, this was the largest, most numerous, longest lasting strike in the long history of trade unions. The Editor-in-Chief wrote in "Głos Nauczycielski" magazine:

Teachers went on strike hoping that the closed schools would open other people's eyes to the problems of education. And they largely succeeded. Although the protest was difficult for the students, and the pro-government propaganda was setting public opinion against the educators, people had positive feelings towards the strikers. And the opinions that this is an individual, selfish action, although they always hurt, were not so frequent. The unprecedented public support for the revolt in education is another issue.

The strike has turned the previously divided, atomized educational environment into a force to be taken into account by those at the helm. They must take it into account, even if they wear stone masks in front of the cameras. Every government, also the next one! (GN no. 18/19 of 8 May 2019).

What did the strike mean for teachers, what were their expectations and hopes, what social forces supported it, what was the dynamics of the protest and how teachers assess its effects? Such questions are limited to a narrow one-sided perspective. They only present a teacher's point of view when confronted with the government. They concentrate around the issue of teacher resistance, relatively unknown in Polish pedagogical literature, understood as an action against the government utilizing various mechanisms of domination and subordination. The long-lasting and progressive pauperization of the teaching profession, the refusal to recognize the teacher's strike demands, ignorance and disregard have put the educational authorities in the role of oppressors. Moreover, there have been clear attempts of the authorities and the government media to manipulate the partitions and intimidate strikers. The Ministry of National Education, the Prime Minister's Office, as well as parliamentary committees launched a whole repertoire 
of oppressive actions, and in addition, superficial "negotiation proposals" appeared in the public space.

How to analyze this clash of power with teacher resistance? Ewa Bilska, referring to the theory of social pedagogy, shows that resistance is based, on the one hand, on the sense of deprivation of essential needs of individuals or groups, and on the other hand, on social and cultural capital, which allows to activate means of action (Bielska 2013, p. 47). Two opposing tendencies emerged in the teacher's strike. On the one hand, it was an attempt to negate the sense of deprivation of needs. The government media repeatedly presented various data indicating high incomes of teachers. They did not relativize them in comparison with other groups of the national economy, but with the specific working time of a teacher. Various teacher's voices became an answer: e.g.: "We are tired of being the Siłaczki. We want to make a decent living. I earn 2100 and I protest" (Anna Zając, GN 2019 no. 4, dated 23.01).

On the other hand, the teachers' strike showed what social capital this professional group has at its disposal. The strike was supported by various organizations and environments: National Association of Educational Management Staff (Ogólnopolskie Stowarzyszenie Kadry Kierowniczej Oświaty), National Forum of Non-Public Education (Krajowe Forum Oświaty Niepublicznej), Movement of Socially Involved Pedagogues (Ruch Pedagogów Społecznie Zaangażowanych) at KNP PAN. The letter of support was submitted by many prominent representatives of the academic community. This voice was joined by local government officials from the Union of Polish Cities (Zwiazek Miast Polskich), as well as parents associated in the Parents' Initiative "Stop the educational nightmare" (Zatrzymać Edukoszmar), the Parents against Education Reform movement (Rodzice przeciwko Reformie Edukacji), Parents have a Voice (Rodzice mają Głos), Forum of Parents' Councils (Forum Rad Rodziców). Constructive proposals to resolve the payroll dispute submitted by representatives of the Business Centre Club, the "Lewiatan" Confederation, Employees of the Republic of Poland and the Polish Craft Association (Związek Rzemiosła Polskiego) were completely ignored by the government authorities.

Different voices appearing in the public space at first showed great public support for the teachers' strike. At the beginning, the strike was supported by more than $52 \%$ of citizens, already the initial survey carried out by Kantar Public, CEBOS indicated that it is related to the political preferences of respondents (CEBOS 2019, no. 54). This indicator has been steadily decreasing. A survey conducted by the IBRiS for Dziennik Gazeta Prawna daily newspaper on 29 April 2019, two days after the suspension of the strike, 
showed that more than half of the respondents felt that neither teachers nor the government came out victorious from the strike.

Let us leave the analysis of the political consequences of the teachers' strike to political scientists. For a pedagogue, the basic question is about the social and educational current and deferred effects of a teacher's protest. Tomasz Szkudlarek, when analyzing the phenomenon of resistance, points out that it is a reflective and intentional activity. It is a derivative of the refusal to recognize a certain state, to reject it (Szkudlarek, 1993). Teachers articulated their protest very clearly. The trade union magazine Głos Nauczycielski moderately and with a great distance reported on the course and dynamics of the strike. The journal gave the floor to practicing teachers who were awarded the Teacher of the Year award. Here are a few of such statements:

I observe teachers, they are tired, frustrated, overwhelmed. They work in a few places. Because they have to. I observe students. The same can be said regarding them. They experience difficulties, they are demotivated, they see no point" (Katarzyna Nowak Zawadzka - Teacher of the Year 2015; GN 2019, no. 14 of 3.04.2019).

I will go on strike because I know that great teachers are leaving the profession because their social position is weakening, they do not want to teach dry academic knowledge, they do not agree with the current educational policy of the government (Joanna Urbańska - Teacher of the Year 2016; GN 2019, no. 14 of 3.04.2019).

I am not a member of any party or trade union. I will go on strike because I want to teach, not to implement an overloaded core curriculum (Marta Florkiewicz-Borkowska - Teacher of the Year 2017; GN 2019, no. 15 of 10.04.2019).

Guess what kind of country it is, where the teacher shapes the next generations in a state of frustration and anxiety, and they absorb frustration and anxiety, like a sponge? (Przemysław Staron - Teacher of the Year 2018; GN 2019, no. 14 of 3.04.2019).

Teachers' statements clearly show how exhausted is the intellectual matrix of a teacher submissive to authorities, obediently performing their tasks in the name of higher values. Teachers' resistance became an expression of reflection on the work and condition of the teaching profession. It also expressed determination taking into account destabilizing measures that were to show the strength of the strikers and their strong disagreement with the current state of affairs. 
Such a stance is documented by teachers' statements:

This is no longer a strike only for money and a raise, but for the future of the Polish school, for the improvement of the public perception of our professional group (Agata Kołodziejczyk; GN 2019, no. 14 of 3.04.2019).

Unfortunately, we are currently witnessing a final degradation of the status of the teaching profession, mostly due to low wages, especially in comparison with other professional groups [...] The prestige of the teaching profession has been greatly eroded -

wrote the representatives of the Business Centre Club (GN 2019, no. 16/17 of 18.04.2019).

Resistance is an action, it is a protest against the power limiting the autonomy of an individual or a group, weakening their sense of causality. Tomasz Szkudlarek, referring to Michel Foucault, combines resistance against authorities with construction of a subject or subjectivity. It is a construct referring to the rejection of dominance, to the affirmation of freedom and to the reference to reason, enlightenment or reflectiveness as understood in a modern way. Ewa Bielska combines this reflectiveness with the empowerment category typical for social pedagogy and social work (Bielska 2013). Resistance, as Bielska shows, is a "rational action" bringing immediate or deferred benefits and losses. They reveal themselves in the social or individual sphere, create various identities, generate multiple strategies and types of action, from escalation of conflict to hidden, niche activities of building alternative solutions or destruction of the system.

Suspension of the strike did not become a game with the oppressive authorities. It does not end the teachers' resistance. However, it gives it a different shape and rank. It is a specific experience. It activates new resources of reflectiveness, differently models individual and collective subjectivity of teachers. It encourages the redefinition of such categories as: democracy, socialization, school community. The strike was a lesson of social education for teachers, parents of students, it gave the public an insight into the situation of teachers and schools. It raised again the questions of freedom, teachers' agency, autonomy of action, the social status of the teachers' profession and the place of education in state politics.

What will be the consequences of the greatest strike in the history, to which teachers were forced by the current authorities? What effects will the strike have for the teachers themselves and for the Polish school? We have 
launched a team research on this subject ${ }^{2}$, but the most important answer will be brought by the next school year.

\section{References}

Bielska E., 2013, Koncepcje oporu we wspótczesnych naukach społecznych. Główne problemy, pojęcia, rozstrzygnięcia, Wydawnictwo Uniwersytetu Śląskiego, Katowice.

Dobrołowicz J., 2013, Obraz edukacji w polskim dyskursie prasowym, Oficyna Wydawnicza "Impuls", Kraków.

Dolata R., 2005, Najważniejsze wyzwania stojące przed polską oświatą. Analizy i Opinie, no. 45, Instytutu Spraw Publicznych, Warszawa:

Domecka M., 2013, Wprowadzenie, [in:] M.S. Archer, Człowieczeństwo: problem sprawstwa, Zakład Wydawniczy Nomos, Kraków.

Gozdawska E., Uryga D., 2014, Rada szkoły; między społeczną idea a praktyką, Wydawnictwo Akademii Pedagogiki Specjalnej, Warszawa:

Gulczyńska J., Jamrożek W., 2013, Opozycyjna działalność nauczycieli w Polsce w latach osiemdziesiątych (wprowadzenie do problemu), [in:] Zaangażowanie? Opór? Gra? Szkic do portretu nauczyciela PRL-u, ed. R. Grzybowski, pp. 175-191.

Kozakiewicz M., 1961, Światopogląd 1000 nauczycieli. Sprawozdanie z badań ankietowych, PZWS, Warszawa.

Kędzierska H., 2012, Kariery zawodowe nauczycieli. Konteksty - Wzory - Pola dyskursu, Wydawnictwo Adam Marszałek, Toruń.

Lutyński J., 1990, Nauka i polskie problemy społeczne. Komentarz socjologa, PIW, Warszawa.

Malinowski T., 1968, Nauczyciel i społeczeństwo, PWN, Warszawa.

Mendel M., 2017, Pedagogika miejsca wspólnego. Miasto i szkoła, Wydawnictwo Naukowe Katedra, Gdańsk.

Mendel M., 2019, Socialized school: beetwen de-socialization and re-socialization. Perspective of the pedagogy of common place, "Pedagogika Społeczna", 1, pp. 29-46.

Nowosad I., 2001, Nauczyciel wychowawca czasu polskich przełomów, Oficyna Wydawnicza "Impuls", Kraków.

Radziewicz J., 1989 Szkoła uspołeczniona i uspołeczniająca, Zespół Oświaty Niezależnej - Zeszyty Edukacji Narodowej, Warszawa.

Rutkowiak J., 1995, Edukacyjna świadomość nauczycieli; intelektualizacja pracy nauczycielskiej jako wyzwanie czasu transformacji, [in:] Odmiany myślenia o edukacji, ed. J. Rutkowiak, Oficyna Wydawnicza "Impuls", Kraków.

Szkudlarek T., 1993, Wiedza $i$ wolność $w$ pedagogice amerykańskiego postmodernizmu, Oficyna Wydawnicza "Impuls", Kraków.

Sztompka P., 1991, Teoria stawania się społeczeństwa. Szkic koncepcji, [in:] Przełom i wyzwanie, eds. A. Sułek, W. Wincławski, Wydawnictwo Adam Marszałek, Warszawa-Toruń.

Śliwerski B., 2013, Diagnoza uspołecznienia publicznego szkolnictwa III RP w gorsecie centrali$z m u$, Oficyna Wydawnicza "Impuls", Kraków.

2 The research project of the Maria Grzegorzewska University "Resistance of teachers to educational realities" (2019-2020). The team: B. Smolińska-Theiss, A. Górka-Strzałkowska, J. Gralewski, E. Strutyńska. 
Śliwerski B., 2013, Nauczyciel PRL $w$ garderobie marksistowskiej pedagogiki, [in:] Zaangażowanie? Opór? Gra? Szkic do portretu nauczyciela PRL-u, ed. R. Grzybowski, Wydawnictwo Adam Marszałek, Toruń.

Śliwerski B., 2015, O konieczności powrotu do subsydiarnej roli państwa w publicznej edukacji szkolnej dzieci i młodzieży, "Pedagogika Społeczna”, 3, s. 17-53.

Śpiewak P., 2004, Obietnice demokracji, Prószyński i S-ka, Warszawa.

\section{Internet sources}

CBOS, 2019, Społeczne poparcie dla protestu nauczycieli; http//chos.pl/SPISKOM.POL/2019/K_054_19.PDF (access date: 25.06.2019).

Education at a Glance, OECD, 2018; https://dx.doi.org/10.1787/eag-2018-en (access date: 03.07.2019).

Głos Nauczycielski, 2019, nr 1-21; wydanie internetowe: http//:ewydanie.glos.pl/

GUS, 2019, Zatrudnienie i wynagrodzenia w gospodarce narodowej w I kwartale 2019; stat.gov.pl (access date: 5.07.2019). 